\title{
Hydrosilane Synthesis by Catalytic Hydrogenolysis of Chlorosilanes and Silyl Triflates
}

\author{
Arne Glüer, ${ }^{[a]}$ Julia I. Schweizer, ${ }^{[b]}$ Uhut S. Karaca, ${ }^{[b]}$ Christian Würtele, ${ }^{[a]}$ Martin Diefenbach, ${ }^{[b]}$ \\ Max C. Holthausen ${ }^{*,[b]}$ and Sven Schneider ${ }^{*},[\mathrm{a}]$ \\ [a] University of Goettingen, Institute for Inorganic Chemistry, Tammannstraße 4, 37077 Göttingen (Germany) \\ ${ }^{[b]}$ Institut für Anorganische und Analytische Chemie, Goethe-Universität, Max-von-Laue-Strasse 7, 60438 Frankfurt \\ am Main (Germany)
}

Silanes, Chlorosilanes, Hydrogenolysis, Catalysis, Pincer Complexes.

\begin{abstract}
Hydrogenolysis of the chlorosilanes and silyl triflates (triflate = trifluoromethanesulfonate, OTf) $\mathrm{Me}_{3-\mathrm{n}} \mathrm{SiX}_{1+\mathrm{n}}$ $(\mathrm{X}=\mathrm{Cl}$, OTf; $\mathrm{n}=\mathrm{o}, 1)$ to hydrosilanes at mild conditions ( 4 bar $\mathrm{H}_{2}$, room temperature) is reported using low loadings (1 mol$\%)$ of the bifunctional catalyst $\left[\mathrm{Ru}(\mathrm{H})_{2} \mathrm{CO}\left(H \mathrm{PNP}^{i P r}\right)\right]\left(\mathrm{PPNP}^{i P r}=H \mathrm{~N}\left(\mathrm{CH}_{2} \mathrm{CH}_{2} \mathrm{P}(i \mathrm{Pr})_{2}\right)_{2}\right)$. Endergonic chlorosilane hydrogenolysis can be driven by chloride removal, e.g. with $\mathrm{NaBAr}_{4}^{\mathrm{F}}\left(\mathrm{BAr}_{4}{ }_{4}-\mathrm{B}_{2}\left(\mathrm{C}_{6} \mathrm{H}_{3}-3,5-\left(\mathrm{CF}_{3}\right)_{2}^{-}\right)\right.$. Alternatively, conversion to silyl triflates enables facile hydrogenolysis with $\mathrm{NEt}_{3}$ as base, giving $\mathrm{Me}_{3} \mathrm{SiH}, \mathrm{Me}_{2} \mathrm{SiH}_{2}$ and $\mathrm{Me}_{2} \mathrm{SiHOTf}$, respectively, in high yields. An outer-sphere mechanism for silyl triflate hydrogenolysis is supported by DFT computations. These protocols provide key steps for the synthesis of the valuable hydrochlorosilane $\mathrm{Me}_{2} \mathrm{SiClH}$, which can also be directly obtained in yields over $50 \%$ by hydrogenolysis of chlorosilane/silyl triflate mixtures.
\end{abstract}

\section{INTRODUCTION}

Organohydrosilanes are important reagents for olefin hydrosilylation $^{1}$ and other applications such as $\mathrm{C}-\mathrm{H}$ bond silylation, ${ }^{2}$ desulfurization of fuels, ${ }^{3}$ or dehydrogenative oligo/polysilane formation. ${ }^{4}$ (Organo)hydrochlorosilane building blocks $\mathrm{SiH}_{\mathrm{x}} \mathrm{Cl}_{\mathrm{y}} \mathrm{R}_{\mathrm{z}}$ enable the orthogonal synthesis of branched polysiloxanes and self-healing silicones by sequential polycondensation and cross-linking via hydrosilylation as used e.g. for the fabrication of release coatings, moldings and adhesives. ${ }^{5}$

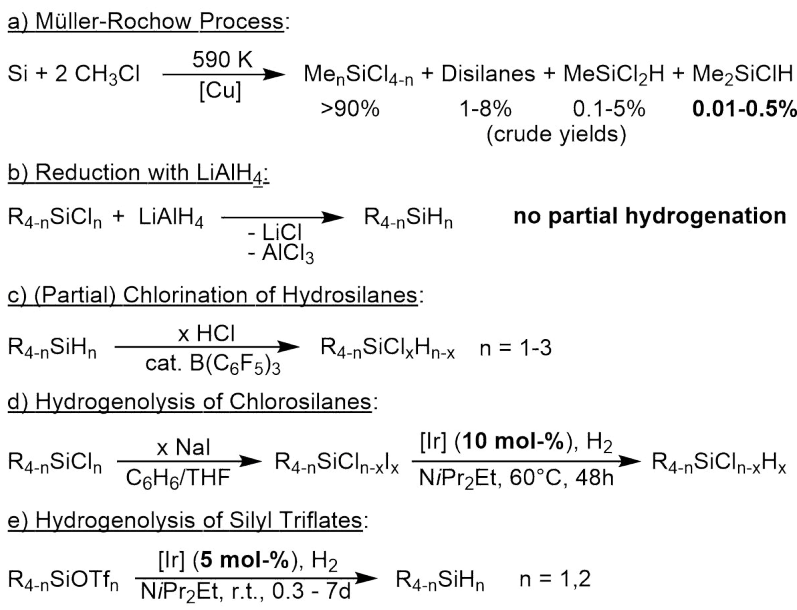

Scheme 1. Synthetic routes to hydro(chloro)silanes.
Some of these precursors, like $\mathrm{MeSiCl}_{2} \mathrm{H}$, are conveniently obtained as a byproduct of the Müller-Rochow process. In contrast, $\mathrm{Me}_{2} \mathrm{SiClH}$ synthesis suffers from low crude yields (o.o1-0.5\%, Scheme 1a) and challenging separation procedures, necessitating alternative synthetic routes to hydro(chloro)silanes from chlorosilanes. ${ }^{6}$ Hydrosilanes can be prepared by salt metathesis from chlorosilanes with $\mathrm{LiAlH}_{4}$ (Scheme ib). Besides the low atom economy that is associated with the use of complex hydride reagents, this approach is not commonly applicable for the synthesis of hydrochlorosilanes due to overreduction. Alternatively, partial chlorination of hydrosilanes, ${ }^{7}$ e.g. selective $\mathrm{B}\left(\mathrm{C}_{6} \mathrm{~F}_{5}\right)_{3}{ }^{-}$ catalyzed hydrosilane acidolysis serves as a versatile route to organohydrochlorosilanes (Scheme 1c). ${ }^{8}$ However, direct organochlorosilane hydrogenolysis as a source of hydrosilanes remains elusive due to the unfavorable thermochemistry $\left(\mathrm{Me}_{3} \mathrm{SiCl}+\mathrm{H}_{2} \rightarrow \mathrm{Me}_{3} \mathrm{SiH}+\mathrm{HCl} ; \Delta G^{0}=+22.2 \mathrm{kcal}\right.$ $\left.\mathrm{mol}^{-1}\right){ }^{8}$

Very recently, Shimada and co-workers pioneered ${ }^{9}$ the hydrogenolysis of silyl triflates and halides $\mathrm{R}_{3-\mathrm{n}} \mathrm{SiX}_{\mathrm{n}+1}$ with iridium catalysts (Scheme $\mathrm{dd} / \mathrm{e}$ ). ${ }^{10}$ With relatively high catalyst loadings (5-10 mol-\%) and long reaction times (2-7 days), moderate yields around $50-60 \%$ in $\mathrm{Me}_{2} \mathrm{SiH}_{2}$ and $\mathrm{Me}_{2} \mathrm{SiHCl}$ could be obtained upon hydrogenolysis of $\mathrm{Me}_{2} \mathrm{SiOTf}_{2}$ or in situ prepared $\mathrm{Me}_{2} \mathrm{SiI}_{2}$ and $\mathrm{Me}_{2} \mathrm{SiICl}$, respectively. Guided by our recent work on de-/hydrogenation with bifunctional catalysts, ${ }^{11}$ we here report ruthenium 
catalyzed hydrogenolysis of chlorosilanes and silyl triflates with low catalyst loadings.

\section{RESULTS AND DISCUSSION}

The considerably higher $\mathrm{Si}-\mathrm{Cl}\left(\sim 100 \mathrm{kcal} \mathrm{mol}^{-1}\right)$ vs. Si-H $\left(\sim 69 \mathrm{kcal} \mathrm{mol}^{-1}\right)$ bond dissociation energy renders hydride vs. chloride metathesis a thermochemically challenging step. $^{12}$ Therefore, a transition metal catalyst with low M-H hydricity ${ }^{13,14}$ was targeted, as indicated e.g. by the capability to catalyze the hydrogenation of $\mathrm{CO}_{2}$ to formate $\left(\Delta G_{\mathrm{H}-}^{\mathrm{o}}\right.$ $\left(\mathrm{HCO}_{2}^{-}\right)=44 \mathrm{kcal} / \mathrm{mol}$ in MeCN$)$. Ruthenium MACHOtype catalysts, i.e. $\left[\mathrm{RuCl}(\mathrm{H}) \mathrm{CO}\left(H \mathrm{PNP}^{R}\right)\right]\left(H \mathrm{PNP}^{R}=\right.$ $\left.\mathrm{HN}\left(\mathrm{CH}_{2} \mathrm{CH}_{2} \mathrm{PR}_{2}\right)_{2}\right)$, show high activities in $\mathrm{CO}_{2}$ hydrogenation. ${ }^{15}$ A stoichiometric control experiment confirmed that the trans-dihydride complex $\left[\mathrm{Ru}(\mathrm{H})_{2}(\mathrm{CO})\left(H \mathrm{PNP}^{i P r}\right)\right]$ (1) readily reacts with $\mathrm{Me}_{3} \mathrm{SiCl}$ to the corresponding hydrosilane in almost quantitative spectroscopic yield (Scheme 2). This observation also demonstrates favorable kinetics for hydride transfer to chlorosilanes with this catalyst class. However, $\mathrm{HCl}$ elimination and $\mathrm{H}_{2}$ heterolysis from the resulting ruthenium chloro complex 2 requires strong bases like alkaline metal hydroxides, alkoxides or amides, which all proved incompatible with chlorosilane substrates. Accordingly, attempts for catalytic hydrogenolysis of $\mathrm{Me}_{3} \mathrm{SiCl}$ in THF with $\mathrm{NEt}_{3}$ as base were unsuccessful. Computational evaluation confirmed endergonic hydrogenolysis with model base $\mathrm{NMe}_{3}\left(\mathrm{Me}_{3} \mathrm{SiCl}+\mathrm{H}_{2}+\mathrm{NMe}_{3} \rightarrow\right.$ $\left.\mathrm{Me}_{3} \mathrm{SiH}+\left[\mathrm{HNMe}_{3}\right] \mathrm{Cl} ; \Delta G^{0}=11.9 \mathrm{kcal} / \mathrm{mol}\right)$, suggesting the requirement of additional driving force to achieve turnover.

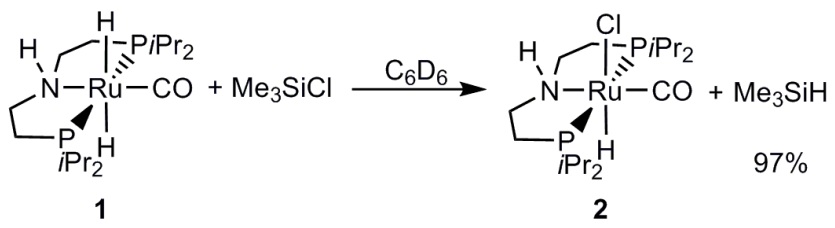

Scheme 2. Stoichiometric hydride transfer of 1 with $\mathrm{Me}_{3} \mathrm{SiCl}$.

In situ chloride precipitation was therefore evaluated as a synthetic strategy. Addition of $\mathrm{NaBAr}_{4}{ }_{4}\left(\mathrm{BAr}_{4}{ }_{4}^{-}=\mathrm{B}\left(\mathrm{C}_{6} \mathrm{H}_{3}-\right.\right.$ 3,5- $\left.\left(\mathrm{CF}_{3}\right)_{2}^{-}\right)$to complex 2 in $\mathrm{PhF}$ as solvent results in the formation of new species by NMR spectroscopy accompanied by $\mathrm{NaCl}$ precipitation (see Electronic Supporting Information, ESI). The ${ }^{31} \mathrm{P}$ and ${ }^{1} \mathrm{H}$ spectroscopic and mass spectrometric data closely resemble the reported values for $\left[\mathrm{Ru}(\mathrm{H}) \mathrm{CO}\left(\mathrm{HPNP}^{i P r}\right)\right] \mathrm{BF}_{4} \cdot{ }^{16}$ Exchange of the solvent with THF- $\mathrm{d}_{8}$ restores 2 , indicating a strong solvent dependence of the chloride abstraction equilibrium.

Chlorosilane hydrogenolysis ( 4 bar $\mathrm{H}_{2}$, r.t.) with 1 (1 mol$\%)$ as catalyst was therefore examined in the presence of stoichiometric amounts of $\mathrm{NaBAr}_{4}^{\mathrm{F}}$ and excess $\mathrm{NEt}_{3}$ as base in PhF. Trimethylchlorosilane as substrate (Table 1, Entry 1) requires relatively long reaction times giving spectroscopic yields in $\mathrm{Me}_{3} \mathrm{SiH}$ around $50 \%$ after about a week. In contrast, hydrogenolysis of $\mathrm{Me}_{2} \mathrm{SiCl}_{2}$ (with 2 eq. $\mathrm{NaBAr}_{4}^{\mathrm{F}}$ ) to $\mathrm{Me}_{2} \mathrm{SiH}_{2}$ proceeds at a much faster rate within a day in yields up to around $80 \%{ }^{17}$ under otherwise identical conditions (Entry 2), presumably due to the higher electrophilicity of the substrate. With only 1 eq. $\mathrm{NaBAr}_{4}^{\mathrm{F}}$ (Entry 3), $\mathrm{Me}_{2} \mathrm{SiH}_{2}$ remains the preferred product, leaving almost half of the substrate unreacted. Replacing $\mathrm{NEt}_{3}$ by 2,6-lutidine as base did not give any hydrogenolysis product even after several days under otherwise identical conditions.

Table 1. Hydrogenolysis of chlorosilanes with catalyst 1. ${ }^{[a]}$

\begin{tabular}{|c|c|c|c|c|c|}
\hline & & & $\begin{array}{l}\text { bar), NE } \\
\text { [1] (1 n }\end{array}$ & $\begin{array}{l}3, \mathrm{PhF}, \\
\mid-\%)\end{array}$ & \\
\hline $\begin{array}{l}n=0,1 \\
\text { n }\end{array}$ & & & $\begin{array}{r}{\left[\mathrm{HNEt}_{3}\right][\mathrm{E}} \\
-\mathrm{NaO}\end{array}$ & $\left.\mathrm{rF}_{4}\right]$ & \\
\hline Entry & Substrate & $\begin{array}{c}\mathrm{NaBAr}_{4}^{\mathrm{F}} \\
\text { (eq.) }\end{array}$ & $\underset{[b]}{\text { Conv. }}$ & $\begin{array}{l}\text { Product } \\
\left.\text { (Yield }^{[\mathrm{b}]}\right)\end{array}$ & $\begin{array}{l}\text { Rxn. } \\
\text { time }\end{array}$ \\
\hline 1 & $\mathrm{Me}_{3} \mathrm{SiCl}$ & 1.1 & $77 \%$ & $\begin{array}{c}\mathrm{Me}_{3} \mathrm{SiH} \\
(51 \%)\end{array}$ & $195 \mathrm{~h}$ \\
\hline 2 & $\mathrm{Me}_{2} \mathrm{SiCl}_{2}$ & 2.0 & $100 \%$ & $\begin{array}{c}\mathrm{Me}_{2} \mathrm{SiH}_{2} \\
(75 \%)\end{array}$ & $24 \mathrm{~h}$ \\
\hline 3 & $\mathrm{Me}_{2} \mathrm{SiCl}_{2}$ & 1.1 & $59 \%$ & $\begin{array}{c}\mathrm{Me}_{2} \mathrm{SiH}_{2} \\
(37 \%)\end{array}$ & $20 h$ \\
\hline
\end{tabular}

[a] General conditions: $0.027 \mathrm{mmol}$ chlorosilane, 0.03 or $0.054 \mathrm{mmol} \mathrm{NaBAr}_{4}^{\mathrm{F}}, 0.26 \mu \mathrm{mol} \mathbf{1}, 0.36 \mathrm{mmol} \mathrm{NEt}_{3}, 0.5 \mathrm{~mL}$ $\mathrm{PhF}, 4$ bar $\mathrm{H}_{2}$, r.t. [b] Conversions/Yields were determined by ${ }^{1} \mathrm{H}$ NMR integration of all signals in the $\mathrm{Me}_{2} \mathrm{Si}$ region around o ppm vs. an internal standard (1,2,4,5-tetramethylbenzene). [c] Conversion of $\left[\mathrm{Me}_{3} \mathrm{SiNEt}_{3}\right]\left[\mathrm{BAr}_{4}^{\mathrm{F}}\right]$ is given.

Catalytic attempts with other alkaline metal salts of weakly coordinating anions (WCA), such as $\mathrm{NaOTf}, \mathrm{KPF}_{6}, \mathrm{NaBPh}_{4}$, $\mathrm{NaSbF}_{6}$ or $\mathrm{NaBF}_{4}$, only gave (sub-)stoichiometric hydrosilane yields with respect to catalyst loading even at high substrate conversion (see ESI). To clarify the role of the WCA, the catalytic reaction with $\mathrm{NaBAr}_{4}^{\mathrm{F}}$ was monitored by NMR spectroscopy. The experiment revealed the presence of an intermediate with a ${ }^{29} \mathrm{Si}$ resonance of 47.4 ppm, i.e. characteristic for base stabilized silyl cations. ${ }^{18}$ The same species is obtained upon mixing $\mathrm{Me}_{3} \mathrm{SiCl}$ with $\mathrm{NaBAr}_{4}^{\mathrm{F}}$ and $\mathrm{NEt}_{3}$ in $\mathrm{PhF}$ in the absence of catalyst. Furthermore, $\mathrm{NEt}_{3}$ coordination to silicon is evidenced by a cross peak of the amine methylene protons with the ${ }^{29} \mathrm{Si}$ resonance in the ${ }^{1} \mathrm{H}^{29} \mathrm{Si} \mathrm{HMBC}$ spectrum (Figure 1). These results suggest that in situ formed $\left[\mathrm{Me}_{3} \mathrm{SiNEt}_{3}\right]^{+}$is the actual substrate, which is sufficiently stabilized by the $\mathrm{BAr}_{4}^{\mathrm{F}}{ }_{4}$ anion under catalytic conditions. ${ }^{19}$

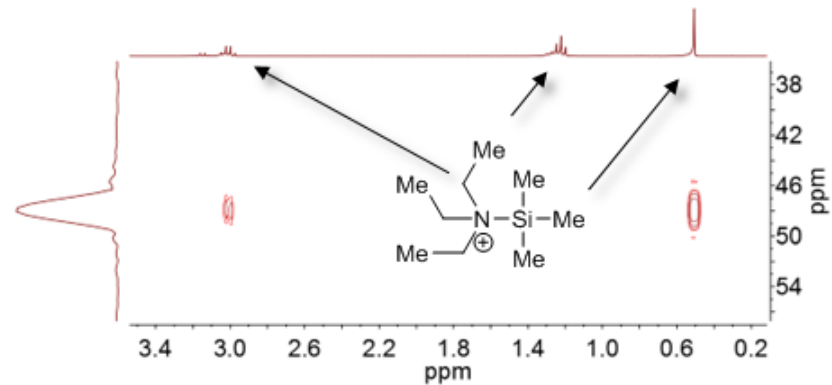

Figure 1. ${ }^{1} \mathrm{H}^{2}{ }^{29} \mathrm{Si} \mathrm{HMBC}$ spectrum of the product from the reaction of $\mathrm{Me}_{3} \mathrm{SiCl}$ with $\mathrm{NaBAr}_{4}^{\mathrm{F}}$ and $\mathrm{NEt}_{3}$. 
Table 2. Hydrogenolysis of silyl triflates with catalyst $\mathbf{1}^{[\mathbf{a}]}$

\begin{tabular}{|c|c|c|c|c|c|}
\hline \multirow{2}{*}{\multicolumn{2}{|c|}{$\begin{array}{l}\mathrm{Me}_{3-\mathrm{n}} \mathrm{SiOTf}_{\mathrm{n}+1}- \\
\mathrm{n}=0,1\end{array}$}} & \multicolumn{4}{|c|}{$\begin{array}{l}\mathrm{H}_{2}(1-4 \mathrm{bar}), \mathrm{NEt}_{3}, \mathrm{C}_{6} \mathrm{D}_{6} \\
\text { r.t., [1] }(0.1-1 \mathrm{~mol}-\%)\end{array}$} \\
\hline & & \multicolumn{2}{|c|}{ - $\left[\mathrm{HNEt}_{3}\right][\mathrm{OTf}]$} & $\longrightarrow \mathrm{Me}_{3}$ & 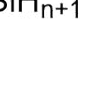 \\
\hline Entry & Substrate & $\begin{array}{l}\text { Base } \\
\text { (eq.) }\end{array}$ & $\underset{[b]}{\text { Conv. }}$ & $\begin{array}{l}\text { Product } \\
\left(\text { Yield }^{[b]}\right)\end{array}$ & $\begin{array}{l}\text { Rxn. } \\
\text { time }\end{array}$ \\
\hline 1 & $\mathrm{Me}_{3} \mathrm{SiOTf}$ & $\begin{array}{c}\mathrm{NEt}_{3} \\
(1.1)\end{array}$ & $99 \%$ & $\begin{array}{c}\mathrm{Me}_{3} \mathrm{SiH} \\
(85 \%)\end{array}$ & $18 \mathrm{~h}$ \\
\hline $2^{[c]}$ & $\mathrm{Me}_{3} \mathrm{SiOTf}$ & $\begin{array}{c}\mathrm{NEt}_{3} \\
(1.1)\end{array}$ & $92 \%$ & $\begin{array}{c}\mathrm{Me}_{3} \mathrm{SiH} \\
(82 \%)\end{array}$ & $46 h$ \\
\hline $3^{[\mathrm{d}]}$ & $\mathrm{Me}_{3} \mathrm{SiOTf}$ & $\begin{array}{l}\mathrm{NEt}_{3} \\
\text { (1.0) }\end{array}$ & $90 \%$ & $\begin{array}{c}\mathrm{Me}_{3} \mathrm{SiH} \\
(85 \%)\end{array}$ & $26 \mathrm{~h}$ \\
\hline $4^{[\mathrm{d}]}$ & $\begin{array}{l}t \mathrm{BuMe}_{2} \mathrm{SiO} \\
\text { Tf }\end{array}$ & $\begin{array}{c}\mathrm{NEt}_{3} \\
(1.1)\end{array}$ & $3 \%$ & $<1 \%$ & $7 \mathrm{~d}$ \\
\hline 5 & $\mathrm{Me}_{2} \mathrm{SiOTf}_{2}$ & $\begin{array}{l}\mathrm{NEt}_{3} \\
(2.2) \\
\end{array}$ & $100 \%$ & $\begin{array}{c}\mathrm{Me}_{2} \mathrm{SiH}_{2} \\
(82 \%)\end{array}$ & $\mathrm{lh}$ \\
\hline 6 & $\mathrm{Me}_{2} \mathrm{SiOTf}_{2}$ & $\begin{array}{l}\mathrm{NEt}_{3} \\
(1.0)\end{array}$ & $99 \%$ & $\begin{array}{c}\mathrm{Me}_{2} \mathrm{SiHOTf} \\
(82 \%) \\
\mathrm{Me}_{2} \mathrm{SiH}_{2} \\
(4 \%)\end{array}$ & $\mathrm{lh}$ \\
\hline
\end{tabular}

[a] General conditions: 0.1 mmol substrate, $1 \mu \mathrm{mol} \mathbf{1}, 4$ bar $\mathrm{H}_{2}$, $0.5 \mathrm{ml} \mathrm{C}_{6} \mathrm{D}_{6}$, r.t. [b] Conversions/Yields were determined by ${ }^{1} \mathrm{H}$ NMR integration of all signals in the MexSi region around o ppm vs. an internal standard (1,2,4,5-tetramethylbenzene)). [c] $0.1 \mu \mathrm{mol} 1$ (o.1 mol-\%). [d] 1.2 bar $\mathrm{H}_{2}$ was used.

Alternative hydrogenolysis strategies were examined to avoid the stoichiometric use of expensive $\mathrm{NaBAr}_{4}^{\mathrm{F}}$ as chloride scavenger. Silyl triflates can be easily obtained from organochlorosilanes and HOTf with $\mathrm{HCl}$ as the only byproduct, ${ }^{20}$ possibly providing a better leaving group for catalysis. Reaction of 1 with $\mathrm{Me}_{3} \mathrm{SiOTf}$ (1 eq.) in $\mathrm{C}_{6} \mathrm{D}_{6}$ selectively gives $\mathrm{Me}_{3} \mathrm{SiH}$ and $\left[\mathrm{RuH}(\mathrm{OTf}) \mathrm{CO}\left(H \mathrm{PNP}^{i P r}\right)\right]$ (3) by NMR spectroscopy. Complex 3 was independently prepared from 1 with HOTf and fully characterized including single-crystal X-ray diffraction (Figure 2). Importantly, $\mathrm{Me}_{3} \mathrm{SiOTf}$ is hydrogenated (1-4 bar $\mathrm{H}_{2}$, r.t.) to trimethylsilane in benzene with high yield $(>8 \mathrm{o} \%)$ using $\mathrm{NEt}_{3}$ as base (Table 2, Entries 1-3). Full conversion is obtained overnight with 4 bar $\mathrm{H}_{2}$ and 1 mol-\% catalyst. Almost the same yield is achieved after $46 \mathrm{~h}$ with loadings as low as 0.1 mol-\% 1 (Entry 2). Reduction of the $\mathrm{H}_{2}$ pressure (1.2 bar) gives the same yield with only slighty longer reaction times (Entry 3). Hydrogenolysis of $t \mathrm{BuMe}_{2} \mathrm{SiOTf}$ was not successful (Entry 4) presumably due to steric shielding.

In comparison, double hydrogenolysis of the bistriflate substrate $\mathrm{Me}_{2} \mathrm{SiOTf}_{2}$ to $\mathrm{Me}_{2} \mathrm{SiH}_{2}$ is remarkably facile and far more rapid than with the previously reported iridium catalyst (5 mol- $\%$ [Ir], 7 days, $53 \%$ yield). ${ }^{10}$ Full conversion and $82 \%$ yield in dihydrosilane is obtained within only $1 \mathrm{~h}$ (1 mol-\% 1, Entry 5). Furthermore, highly selective semihydrogenolysis is obtained within the same time (Entry 6) using one eq. of base to give $\mathrm{Me}_{2} \mathrm{SiHOTf}$ in $82 \%$ yield.

During the course of catalysis, 3 is the only ruthenium species observed by ${ }^{1} \mathrm{H}$ and ${ }^{31} \mathrm{P}$ NMR spectroscopy. After some time, the conjugate acid [ $\left.\mathrm{HNEt}_{3}\right][\mathrm{OTf}]$ forms a separate ionic liquid phase, which might be beneficial to drive the reaction (see below). Importantly, the substrate, base and catalyst remain dissolved in the benzene layer.

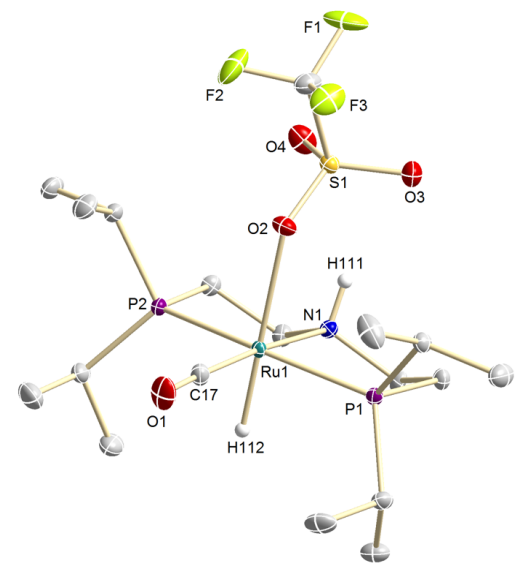

Figure 2. Molecular structure of $\mathbf{3}$ from single-crystal X-ray diffraction (ellipsoids set at 30\% probability, hydrogen atoms except H111 and H112 omitted for clarity). Selected bond lengths $[\AA ̊]$ and angles [deg]: Ru1- $\mathrm{C}_{17}$ 1.8320(16), Ru1-N1 2.1969(13), Ru1-O2 2.2957(11), Ru1-P1 2.3195(4), Ru1-P2 $2.3276(5)$, Ru1-H112 1.52(2), C(17)-Ru(1)-N(1) 175.11(6), N(1)$\mathrm{Ru}(1)-\mathrm{O}(2)$ 90.82(4), $\mathrm{P}(1)-\mathrm{Ru}(1)-\mathrm{P}(2) 164.903(14), \mathrm{O}(2)-\mathrm{Ru}(1)-$ $\mathrm{H}(112)$ 178.3(8).

DFT calculations were performed for the $\mathrm{PMe}_{2}$-truncated model system $\mathbf{1}^{\mathrm{Me}}$ with $\mathrm{NMe}_{3}$ as model base to obtain further insight into the hydrogenolysis mechanism (Scheme 3). Geometry optimizations were performed at the RI-PBE$\mathrm{D}_{3} /$ def2-SVP level of theory. Improved energies were obtained from subsequent SMD-PBEo-D3/def2-TZVP singlepoint calculations validated against explicitly correlated coupled-cluster energies. ${ }^{21}$ The lowest energy pathway commences with a barrierless endergonic adduct formation between $\mathbf{1}^{\mathrm{Me}}$ and $\mathrm{Me}_{3} \mathrm{SiOTf}$ to yield intermediate $\mathbf{I 1}^{\mathrm{Me}}$. Si-O-bond heterolysis proceeds via tss ${ }^{\mathrm{Me}}$ as the turnover limiting transition state of the overall process. This leads to exergonic formation of $\mathbf{I}{ }^{\mathrm{Me}}$, which is stabilized by hydrogen bonding of the OTf anion to the HPNP ligand. Subsequent displacement of $\mathrm{Me}_{3} \mathrm{SiH}$ by the triflate anion exhibits a small activation barrier (10 kcal mol ${ }^{-1}$ via ts2 ${ }^{\mathrm{Me}}$ ). The resulting triflate complex $3^{\mathrm{Me}}$ represents the thermodynamic resting state $\left(\Delta G^{0}=-10.4 \mathrm{kcal} \mathrm{mol}^{-1}\right)$, in line with the experimental observations (see above). Regeneration of $\mathbf{1}^{\mathrm{Me}}$ proceeds without significant barriers and involves $\mathrm{H}_{2}$-binding to $\mathbf{I}_{3}{ }^{\mathrm{Me}}$ followed by base assisted heterolysis via ts4 $^{\mathrm{Me}}$. Overall, hydrogenolysis of $\mathrm{Me}_{3} \mathrm{SiOTf}$ and regeneration of the catalyst is computed to be slightly endergonic. This result suggests that the reaction is partially driven by the $\left[\mathrm{HNMe}_{3}\right]$ OTf ionic liquid phase separation, which was approximated as an isolated contact ion pair in the 

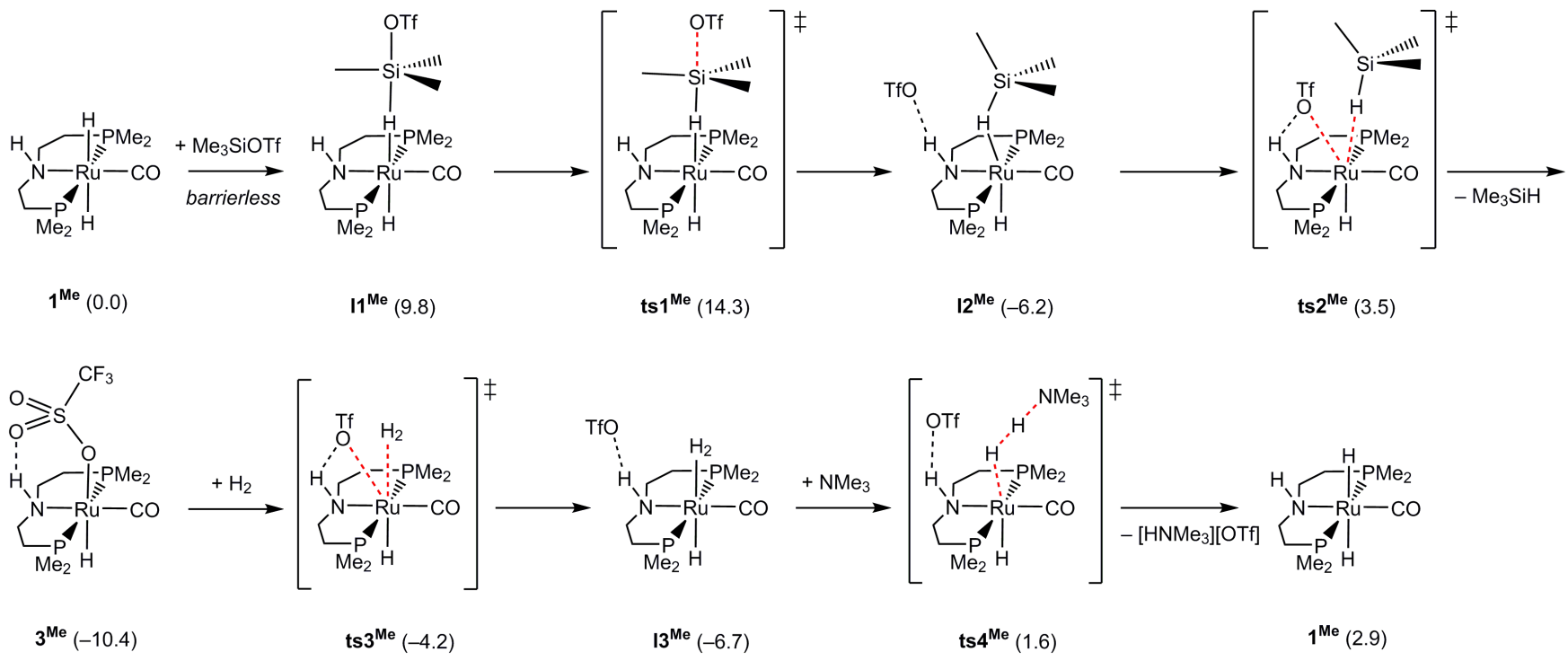

Scheme 3. Computed pathway for the hydrogenolysis of $\mathrm{Me}_{3} \mathrm{SiOTf}_{\text {using }} \mathbf{1}^{\mathrm{Me}} ; \Delta G^{\mathrm{o}}$ in $\mathrm{kcal} \mathrm{mol}^{-1}$ (SMD-PBEo-D $3 / \mathrm{def}_{2}-$ TZVP//RI-PBE-D3/def2-SVP).

$25 \mathrm{kcal} \mathrm{mol}^{-1}$ is therefore estimated from the energy interval between the resting state $3^{\text {Me }}$ and the rate-limiting tsi $^{\mathrm{Me}}$. This value is in agreement with a reaction that proceeds at room temperature. ${ }^{22}$

Resting state $3^{\text {Me }}$ is stabilized by N-H ${ }^{\cdots}$ OTf hydrogen bonding, as confirmed by the experimental structure of 3 (Figure 2). The $N$-methylated catalyst $\left[\mathrm{RuH}(\mathrm{OTf}) \mathrm{CO}\left(\mathrm{MePNP}^{i P r}\right)\right] \quad$ (4, $\mathrm{MePNP}^{i P r}=$ $\left.\mathrm{MeN}\left(\mathrm{CH}_{2} \mathrm{CH}_{2} \mathrm{PiPr}_{2}\right)_{2}\right)$ was therefore employed to probe for rate acceleration by resting state destabilization. The hydrogenolysis rate of $\mathrm{Me}_{3} \mathrm{SiOTf}$ with $\mathrm{NEt}_{3}$ as base is, in fact, slightly increased (91\% conversion after $130 \mathrm{~min}$ ) with respect to 3 (81\% conversion after $135 \mathrm{~min})$ under identical conditions.

$$
2 \mathrm{Me}_{2} \mathrm{SiClOTf} \stackrel{\mathrm{K}_{\mathrm{eq}}=0.07}{\rightleftharpoons} \mathrm{Me}_{2} \mathrm{SiCl}_{2}+\mathrm{Me}_{2} \mathrm{SiOTf}_{2}
$$

Scheme 4. Redistribution of chlorosilanes and silyl triflates.

The hydrogenolysis protocols outlined above provide key precursors for facile organohydrochlorosilane synthesis in high yield at mild conditions with low catalyst loadings. Chlorosilyl triflate semihydrogenolysis could be an alternative route for direct synthesis. $\mathrm{Me}_{2} \mathrm{SiClOTf}$ can be obtained from $\mathrm{Me}_{2} \mathrm{SiCl}_{2}$ with 1 eq. HOTf as main product according to in situ NMR examination. However, isolation attempts by distillation lead to chloride/triflate dismutation (Scheme 4). At r.t. equilibration is slow (ca. $4 \mathrm{~d}$ ), but considerably accelerated upon addition of amines (e.g. $\mathrm{NEt}_{3}$ or 2,6-lutidine) or 1 (ca. $1 \mathrm{~h}){ }^{23}$ Consequently, mixtures of $\mathrm{Me}_{2} \mathrm{SiCl}_{2}$ and $\mathrm{Me}_{2} \mathrm{SiOTf}_{2}$ might be directly used after equilibration under catalytic conditions. Rapid ( $<5 \mathrm{~h})$, full conversion with respect to triflate is obtained with $\mathrm{NEt}_{3}$ as base ( $1 \mathrm{~mol}-\%$ 1). However, $\mathrm{Me}_{2} \mathrm{SiH}_{2}$ is the main hydrogenolysis product $(36 \%){ }^{24}$ The desirable hydrochlorosilane $\mathrm{Me}_{2} \mathrm{Si}$ $\mathrm{ClH}$ is observed only in $5 \%{ }^{24}$ spectroscopic yield, which ratio of 5:1 to reduce the $\mathrm{Me}_{2} \mathrm{SiOTf}_{2}$ equilibrium concentration.

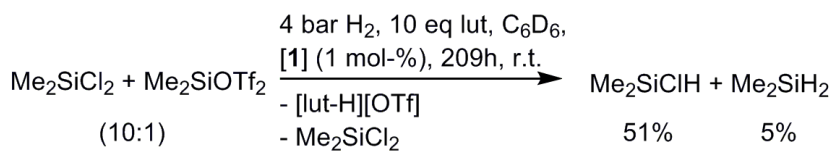

Scheme 5. Hydrogenolysis of a mixture of $\mathrm{Me}_{2} \mathrm{SiCl}_{2}$ and $\mathrm{Me}_{2} \mathrm{SiOTf}_{2}$ with catalyst $\mathbf{1}^{24}$

Screening of other ruthenium, iron and iridium pincer catalysts (see ESI) gave slightly varying dihydrosilane yields. We therefore anticipate kinetic control of the selectivity. Computational evaluation of the $\mathrm{Me}_{2} \mathrm{SiCl}_{2} / \mathrm{Me}_{2} \mathrm{SiH}_{2}$ dismutation equilibrium, in fact, suggests much higher $\mathrm{Me}_{2} \mathrm{SiClH}$ yields under thermodynamic control $\left(\mathrm{Me}_{2} \mathrm{SiCl}_{2}+\mathrm{Me}_{2} \mathrm{SiH}_{2}\right.$ $\left.\rightarrow 2 \mathrm{Me}_{2} \mathrm{SiClH} ; \Delta G^{0}=-0.7 \mathrm{kcal} \mathrm{mol}^{-1}\right)$. In fact, catalytic $\mathrm{R}_{2} \mathrm{SiH}_{2} / \mathrm{R}_{2} \mathrm{SiCl}_{2}$ dismutation to hydrochlorosilanes has been reported in the literature, and the experimentally derived equilibrium constant for $\mathrm{R}=\mathrm{Me}\left(\Delta G_{\text {exp }}^{\mathrm{O}} \approx-1.3 \mathrm{kcal} \mathrm{mol}^{-1}\right)$ is in close agreement with our computational estimate. ${ }^{25}$

As a strategy to maintain thermodynamic control, weaker bases than $\mathrm{NEt}_{3}\left(\mathrm{p} K_{\mathrm{a}, \mathrm{MeCN}}=18.8\right)^{26}$ were screened. With 2,6lutidine $\left(\mathrm{p} K_{\mathrm{a}, \mathrm{MeCN}}=14.1\right)^{27}$ excess base is required for full conversion (97\%). Furthermore, $\mathrm{Me}_{2} \mathrm{SiClH}$ and 2,6lutidinium triflate eliminate dihydrogen under argon suggesting approximately thermoneutral hydrogenolysis with the conjugate base. High selectivities in $\mathrm{Me}_{2} \mathrm{SiClH}$ vs. $\mathrm{Me}_{2} \mathrm{SiH}_{2}$ (> 10:1) are obtained for hydrogenolysis of a $\mathrm{Me}_{2} \mathrm{SiCl}_{2} / \mathrm{Me}_{2} \mathrm{SiOTf}_{2}$ (10:1) ${ }^{28}$ mixture with 2,6-lutidine (10 eq.) as base (Scheme 5). Following the reaction by ${ }^{1} \mathrm{H}$ NMR (Figure 3) reveals that the reaction is considerably slower than bistriflate hydrogenolysis. Furthermore, the selectivity slightly changes over time in favor of $\mathrm{Me}_{2} \mathrm{SiClH}$. Therefore, high substrate conversion (>90\%) and $\mathrm{Me}_{2} \mathrm{SiClH}$ yields over $50 \%{ }^{24}$ require about a week under these conditions. 


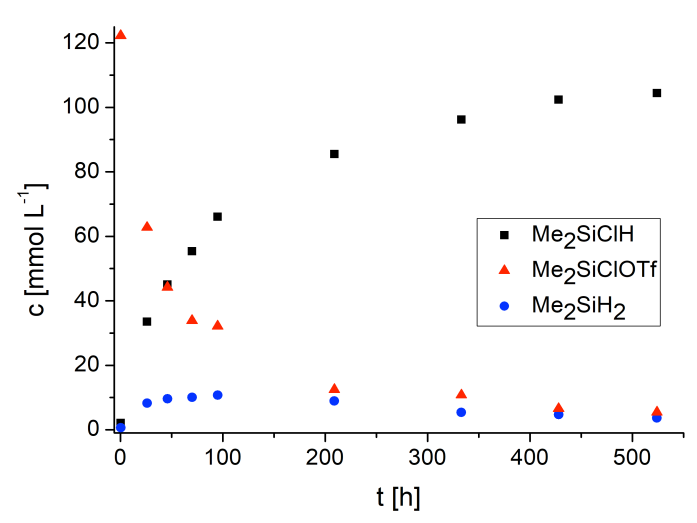

Figure 3. Time-dependent concentration profiles of the reaction depicted in Scheme 5.

In summary, several catalytic hydrogenolysis routes to organohydro- and halohydrosilanes are reported. Mild reaction conditions (1-4 bar $\mathrm{H}_{2}$, r.t.) at low catalyst loadings (o.1-1 mol-\%) and reaction times could be obtained. Especially bistriflate (semi)hydrogenolysis rapidly affords the organohydrosilane building blocks $\mathrm{Me}_{2} \mathrm{SiH}_{2}$ and $\mathrm{Me}_{2} \mathrm{Si}$ HOTf in excellent yields. Experimental and computational evaluation supports a catalytic cycle via outer-sphere hydride transfer and $\mathrm{H}_{2}$ heterolysis. Chlorosilane hydrogenolysis is enabled by chloride precipitation with $\mathrm{NaBAr}_{4}^{\mathrm{F}}$, presumably via base stabilized silyl cations as key intermediates. In combination, the hydrogenolysis of chlorosilane/silyl triflate mixtures can be optimized to directly give the hydrochlorosilane $\mathrm{Me}_{2} \mathrm{SiClH}$ in moderate yields.

\section{EXPERIMENTAL DETAILS}

\section{General Information}

All experiments were carried out under argon (Linde, 5.0) atmosphere using Schlenk or glove-box techniques $\left(\mathrm{O}_{2}\right.$, $\mathrm{H}_{2} \mathrm{O}$ below o.1 ppm). NMR tubes were silanized with $\mathrm{Me}_{2} \mathrm{SiCl}_{2}$ and all glassware was heated in vacuum prior to use. $\mathrm{C}_{6} \mathrm{H}_{6}, \quad \mathrm{Et}_{2} \mathrm{O}$ (stabilized with 2,6-Di-tert-butyl-4methylphenol) and pentane (HPLC grade Roth, VWR or Sigma Aldrich) were degassed and dried by passing through columns packed with activated alumina. Fluorobenzene was degassed and dried over molecular sieves (4 $\AA$ ). Deuterated solvents were purchased from Deutero $\mathrm{GmbH}$ and dried over $\mathrm{CaH}_{2}\left(\mathrm{CD}_{2} \mathrm{Cl}_{2}\right)$ or $\mathrm{Na} / \mathrm{K}\left(\mathrm{THF}-\mathrm{D}_{8}\right.$, $\mathrm{C}_{6} \mathrm{D}_{6}$ ) and trap-to-trap transfer in vacuo. $\mathrm{NEt}_{3}$ was dried over $\mathrm{KOH}$, distilled and stored over Molecular Sieves (4 $\AA$ ). 2,6-lutidine was dried over $\mathrm{AlCl}_{3}$, distilled and stored over molecular sieves (4 ̊̊). $\mathrm{Me}_{3} \mathrm{SiCl}, \mathrm{Me}_{2} \mathrm{SiCl}_{2}, \mathrm{Me}_{2} \mathrm{SiHCl}$, $\mathrm{Me}_{3} \mathrm{SiOTf}, t \mathrm{BuMe}_{2} \mathrm{SiOTf}$ and MeOTf were degassed and distilled prior to use. 1,2,4,5-tetramethylbenzene and $\mathrm{KO} t \mathrm{Bu}$ were sublimed prior to use. $\mathrm{NaBPh}_{4}, \mathrm{NaBF}_{4}$, $\mathrm{NaSbF}_{6}, \mathrm{KPF}_{6}$ and $\mathrm{NaOTf}$ were dried i.vac. prior to use. HOTf (ABCR) was used without further purification. $\mathrm{H}_{2}$ (Linde, 6.0) was dried by passing through a spiral cooling system which was immersed in $\mathrm{N}_{2}(\mathrm{l})$. $\mathrm{NaBAr}_{4}^{\mathrm{F}}, 292,6-$ lutidinium triflate, ${ }^{30} \mathbf{1}^{31}$ and $\mathbf{2}^{32}$ were prepared following published procedures.
NMR spectra were recorded on Bruker Avance III HD 30o, 400 or 500 (w. broadband cryoprobe) spectrometers and calibrated to the residual proton resonance of the solvent $\left(\mathrm{C}_{6} \mathrm{D}_{6}: \delta_{\mathrm{H}}=7.16 \mathrm{ppm} ; \delta_{\mathrm{C}}=128.06 \mathrm{ppm}\right.$, THF- $\mathrm{D}_{8}: \delta_{\mathrm{H}}=1.72$ $\mathrm{ppm} / 3.58 \mathrm{ppm} ; \delta_{\mathrm{C}}=25.31 \mathrm{ppm} / 67.21 \mathrm{ppm}, \mathrm{CD}_{2} \mathrm{Cl}_{2}: \delta_{\mathrm{H}}=$ $\left.5.32 \mathrm{ppm} ; \delta_{\mathrm{C}}=53.84 \mathrm{ppm}\right) .{ }^{31} \mathrm{P}$ and ${ }^{29} \mathrm{Si}$ NMR chemical shifts are reported relative to phosphoric acid $\left(\delta_{\mathrm{P}}=0.0 \mathrm{ppm}\right)$ and $\mathrm{SiMe}_{4}\left(\delta_{\mathrm{Si}}=0.0 \mathrm{ppm}\right)$, respectively. Signal multiplicities were abbreviated as: $\mathrm{s}$ (singlet), $\mathrm{d}$ (doublet), $\mathrm{t}$ (triplet), $\mathrm{q}$ (quartet), p (pentet), sept (septet) $\mathrm{m}$ (multiplet), br (broad). LIFDI mass spectra were measured under inert conditions. Elemental analyses were obtained with an Elementar Vario EL 3 analyzer. IR spectra were recorded as powder on a Bruker ALPHA FT-IR spectrometer with Platinum ATR module.

\section{Catalytic Protocols}

Hydrogenolysis of silyl chlorides: $\mathrm{NaBAr}_{4}^{\mathrm{F}}, \mathbf{1}$ and base were dissolved in PhF in a J Young NMR tube, and the solution was frozen in $\mathrm{N}_{2}(\mathrm{l})$. Chlorosilane was condensed onto the mixture in static vacuum and the headspace was refilled with $\mathrm{H}_{2}$ (1.2 bar). The sample was thawed and immediately shaken. For reactions at 4 bar the NMR tube was nearly completely immersed in $\mathrm{N}_{2}$ (l) for 1 min during addition of $\mathrm{H}_{2}$ before the tube was closed. Products were identified by ${ }^{1} \mathrm{H}$ and ${ }^{1} \mathrm{H}^{29} \mathrm{Si} \mathrm{HMBC}$ spectroscopy and quantified by relative integration of the $\mathrm{Me}_{x} \mathrm{Si}$ signals vs. an internal standard (1,2,4,5-tetramethylbenzene).

Hydrogenolysis of pure silyl triflates: Silyl triflate, $\mathbf{1}$ and base were dissolved in $\mathrm{C}_{6} \mathrm{D}_{6}$ in a J Young NMR tube. The mixture was frozen in $\mathrm{N}_{2}(\mathrm{l})$ and the headspace was evacuated, refilled with $\mathrm{H}_{2}$ (1.2 bar) and sealed. For reactions at 4 bar the NMR tube was nearly completely immersed in $\mathrm{N}_{2}$ (l) for 1 min during addition of $\mathrm{H}_{2}$ before the tube was closed. Products were identified by ${ }^{1} \mathrm{H}$ and ${ }^{1} \mathrm{H}^{29} \mathrm{Si}$ HMBC spectroscopy and quantified by relative integration of the $\mathrm{Me}_{x} \mathrm{Si}$ signals vs. an internal standard (1,2,4,5-tetramethylbenzene)

Hydrogenolysis of Mixtures of silyl triflates and -chlorides: $\mathrm{Me}_{2} \mathrm{SiOTf}_{2}, \mathrm{Me}_{2} \mathrm{SiCl}_{2}$ and catalyst were dissolved in $\mathrm{C}_{6} \mathrm{D}_{6}$ in a J Young NMR tube and shaken for $1.5 \mathrm{~h}$. Base was added and the NMR tube was frozen in $\mathrm{N}_{2}(\mathrm{l})$. The headspace was evacuated, refilled with $\mathrm{H}_{2}$ (1.2 bar) and cooled for $1 \mathrm{~min}$. After sealing, the tube was warmed to room temperature giving a pressure of about 4 bar. Products were identified by ${ }^{1} \mathrm{H}$ and ${ }^{1} \mathrm{H}^{29} \mathrm{Si}$ HMBC spectroscopy and quantified by relative integration of the $\mathrm{Me}_{\mathrm{x}} \mathrm{Si}$ signals vs. an internal standard (1,2,4,5-tetramethylbenzene).

\section{Synthetic Procedures}

Synthesis of $\mathrm{Me}_{2} \mathrm{SiOTf}_{2}: \mathrm{Me}_{2} \mathrm{SiCl}_{2}$ (6.o mL, $0.05 \mathrm{~mol}$, 1.0 eq) is stirred at $\mathrm{O}^{\circ} \mathrm{C}$ and HOTf $(12.5 \mathrm{~mL}, 0.14 \mathrm{~mol}, 2.8 \mathrm{eq})$ added via syringe. The mixture is heated to $60^{\circ} \mathrm{C}$ for $2 \mathrm{~d}$ with occasional removal of the $\mathrm{HCl}$ atmosphere by a stream of Argon. Excess acid was neutralized by careful addition of $\mathrm{NEt}_{3}(8 \mathrm{~mL}, 0.07 \mathrm{~mol}, 1.4 \mathrm{eq})$ at $\mathrm{o}^{\circ} \mathrm{C}$. Removal of volatiles $i$. vac. and distillation $\left(0.3 \mathrm{mbar}, 37^{\circ} \mathrm{C}\right)$ gave $\mathrm{Me}_{2} \mathrm{SiOTf}_{2}$ as a colorless oil ( $9 \mathrm{~mL}, 0.04 \mathrm{~mol}, 79 \%$ ) in $97 \%$ purity according to ${ }^{1} \mathrm{H}$ and ${ }^{19} \mathrm{~F}$ NMR. ${ }^{1} \mathrm{H}$ NMR $(300.13 \mathrm{MHz}$, $\left.\mathrm{C}_{6} \mathrm{D}_{6}, \quad 300 \mathrm{~K}\right): \delta(\mathrm{ppm})=-0.01 \quad\left(\mathrm{~s}, \quad \mathrm{CH}_{3}\right) .{ }^{19} \mathrm{~F} \quad \mathrm{NMR}$ $\left(282.37 \mathrm{MHz}, \mathrm{C}_{6} \mathrm{D}_{6}, 298 \mathrm{~K}\right): \delta(\mathrm{ppm})=-76.66\left(\mathrm{~s}, \mathrm{CF}_{3}\right) .{ }^{29} \mathrm{Si}$ 
NMR $\left(59.63 \mathrm{MHz}, \mathrm{C}_{6} \mathrm{D}_{6}, 298 \mathrm{~K}\right): \delta(\mathrm{ppm})=-14.6$ (determined by $\left.{ }^{1} \mathrm{H}^{29} \mathrm{Si} \mathrm{HMBC}\right)$.

Synthesis of $\left[R u H(O T f) C O\left(H P N P^{i P r}\right)\right] \quad$ (3): $\left[\mathrm{Ru}(\mathrm{H})_{2} \mathrm{CO}\left(\mathrm{HPNP}^{\mathrm{iPr}}\right)\right](\mathbf{1})$ (100 $\mathrm{mg}, 0.23 \mathrm{mmol}$, 1.o eq) is dissolved in $\mathrm{Et}_{2} \mathrm{O}(6 \mathrm{~mL})$ in a J Young flask and HOTf $(20 \mu \mathrm{L}$, $0.23 \mathrm{mmol}, 1.0 \mathrm{eq}$ ) is added. The solution is evaporated to $5 \mathrm{~mL}$ i.vac. and the precipitated product decanted off. After washing with pentane $(3 \times 3 \mathrm{~mL})$ and drying i.vac., crude (99.5\% purity) 3 (80 $\mathrm{mg}, 0.14 \mathrm{mmol}, 60 \%$ ) is obtained as white solid. After lyophilization, a suspension in $\mathrm{Et}_{2} \mathrm{O}$ $(0.5 \mathrm{~mL})$ is stirred over night, decanted off and dried i.vac. to give 3 as white solid (75 mg, $0.13 \mathrm{mmol}, 56 \%)$. Crystals suitable for $\mathrm{X}$-ray crystallography were grown by cooling a saturated $\mathrm{Et}_{2} \mathrm{O}$ solution to $\left.-40{ }^{\circ} \mathrm{C} .{ }^{1} \mathrm{H}^{\left\{{ }^{3}\right.} \mathrm{P}\right\} \quad \mathrm{NMR}$ $\left(500.25 \mathrm{MHz}, \quad \mathrm{C}_{6} \mathrm{D}_{6}, \quad 298 \mathrm{~K}\right): \delta(\mathrm{ppm})=4.52(\mathrm{t}(\mathrm{br})$, $\left.{ }^{3} J_{\mathrm{HH}}=11.3 \mathrm{~Hz}, 1 \mathrm{H}, \mathrm{NH}\right), 2.68\left(\right.$ hept $\left.^{3} J_{\mathrm{HH}}=7.3 \mathrm{~Hz}, 2 \mathrm{H}, \mathrm{CH}^{\text {syn }}\right)$, $2.44\left(\mathrm{~m}, 2 \mathrm{H}, \mathrm{NCH}_{2}\right), 1.88\left(\mathrm{~m}, 2 \mathrm{H}, \mathrm{PCH}_{2}\right), 1.78$ (hept, $\left.{ }^{3} J_{\mathrm{HH}}=6.9 \mathrm{~Hz}, 2 \mathrm{H}, \mathrm{CH}\right), 1.55\left(\mathrm{~m}, 4 \mathrm{H}\right.$, superposition of $\mathrm{PCH}_{2}$ and $\left.\mathrm{NCH}_{2}\right), 1.52\left(\mathrm{~d}, 33_{\mathrm{HH}}=7.3 \mathrm{~Hz}, 6 \mathrm{H}, \mathrm{CH}_{3}\right), 1.03(\mathrm{~d}$, $\left.{ }^{3} J_{\mathrm{HH}}=6.9 \mathrm{~Hz}, 6 \mathrm{H}, \mathrm{CH}_{3}{ }^{a n t i}\right), 1.00\left(\mathrm{~d},{ }^{3} J_{\mathrm{HH}}=7.3 \mathrm{~Hz}, 6 \mathrm{H}, \mathrm{CH}_{3}\right)$, $0.73\left(\mathrm{~d},{ }^{3} J_{\mathrm{HH}}=6.9 \mathrm{~Hz}, 6 \mathrm{H}, \mathrm{CH}_{3}\right),-20.9(\mathrm{~s}, 1 \mathrm{H}, \mathrm{Ru}-\mathrm{H}$ $\left({ }^{2} J_{\mathrm{HP}}=18.0 \mathrm{~Hz}\right.$ by ${ }^{1} \mathrm{H}$ NMR $\left.)\right) .{ }^{13} \mathrm{C}\left\{{ }^{1} \mathrm{H}\right\}$ NMR $(125.80 \mathrm{MHz}$, $\left.\mathrm{C}_{6} \mathrm{D}_{6}, 298 \mathrm{~K}\right): \delta(\mathrm{ppm})=205.5\left(\mathrm{t},{ }^{2} J_{\mathrm{CP}}=11.5 \mathrm{~Hz}, \mathrm{CO}\right), 120.2$ (obtained by ${ }^{19} \mathrm{~F}^{-13} \mathrm{C}$ HSQC), 54.o (vt, $\mathrm{N}=\left|{ }^{1} J_{\mathrm{CP}}+{ }^{3} J_{\mathrm{CP}}\right|$ $\left.=8.8 \mathrm{~Hz}, \mathrm{NCH}_{2}\right), 29.6\left(\mathrm{vt}, \mathrm{N}=\left|{ }^{2} J_{\mathrm{CP}}+{ }^{3} J_{\mathrm{CP}}\right|=18.5 \mathrm{~Hz}, \mathrm{PCH}_{2}\right)$, 28.1 (vt, $\left.\mathrm{N}=\left|{ }^{1} J_{\mathrm{CP}}+{ }^{3} J_{\mathrm{CP}}\right|=21.6 \mathrm{~Hz}, \mathrm{CH}\right), 23.9$ (vt, $\mathrm{N}=\mid{ }^{1} J_{\mathrm{CP}}+$ $\left.{ }^{3} J_{\mathrm{CP}} \mid=26.1 \mathrm{~Hz}, \mathrm{CH}^{\text {anti }}\right), 20.7\left(\mathrm{vt}, \mathrm{N}=\left|{ }^{2} J_{\mathrm{CP}}+{ }^{4} J_{\mathrm{CP}}\right|=6.5 \mathrm{~Hz}\right.$, $\mathrm{CH}_{3}$ ), 20.1 (vt, $\mathrm{N}=\left|{ }^{2} J_{\mathrm{CP}}+{ }^{4} J_{\mathrm{CP}}\right|=6.5 \mathrm{~Hz}, \mathrm{CH}_{3}$ ), 18.7 (vt, br, $\left.\mathrm{N}=\left|{ }^{2} J_{\mathrm{CP}}+{ }^{4} J_{\mathrm{CP}}\right|=1.9 \mathrm{~Hz}, \mathrm{CH}_{3}\right), 16.9$ (vt, $\mathrm{N}=\left|{ }^{2} J_{\mathrm{CP}}+{ }^{4} J_{\mathrm{CP}}\right|$ $\left.=3.5 \mathrm{~Hz}, \mathrm{CH}_{3}\right)$. Assignments were confirmed by $2 \mathrm{D}-\mathrm{NMR}$. ${ }^{31} \mathrm{P}\left\{{ }^{1} \mathrm{H}\right\}$ NMR (202.52 MHz, $\left.\mathrm{C}_{6} \mathrm{D}_{6}, 298 \mathrm{~K}\right): \delta(\mathrm{ppm})=73.8(\mathrm{~s})$. ${ }^{19} \mathrm{~F}$ NMR $\left(470.67 \mathrm{MHz}, \mathrm{C}_{6} \mathrm{D}_{6}, 298 \mathrm{~K}\right): \delta(\mathrm{ppm})=-77.6(\mathrm{~s})$. LIFDI-MS: $\mathrm{m} / \mathrm{z}(\%)=585.0(100)[\mathrm{M}]^{+}, 436.1(80)[\mathrm{M}-\mathrm{OTf}]^{+}$. IR: $v\left(\mathrm{~cm}^{-1}\right): 3248(\mathrm{~N}-\mathrm{H}), 2934,2871,2035(\mathrm{Ru}-\mathrm{H}), 1920$ $(\mathrm{C} \equiv \mathrm{O}), 1879,1468,1278,1231,1221,1214,1188,1164,1025,829$, 636, 622. Anal. calcd for $\mathrm{C}_{18} \mathrm{H}_{38} \mathrm{~F}_{3} \mathrm{NO}_{4} \mathrm{P}_{2} \mathrm{RuS}$ : C, 36.98; $\mathrm{H}$, 6.55; N, 2.40. Found: C, 37.13; H, 6.42; N, 2.34.

Synthesis of $\left[R u H(O T f) C O\left(M e P N P^{i P r}\right)\right]: \quad 2 \quad(35.3 \mathrm{mg}$, $74.3 \mu \mathrm{mol}$, 1.o eq) and $\mathrm{KO}^{t} \mathrm{Bu}(10.1 \mathrm{mg}$, $90 \mu \mathrm{mol}$, $1.2 \mathrm{eq})$ are suspended in $\mathrm{Et}_{2} \mathrm{O}(2 \mathrm{~mL})$ and stirred for $3 \mathrm{~h}$ at r.t. The mixture is filtered through a fritted funnel and the resulting yellow solution dried i.vac. After extraction with pentane (4x4 mL total) MeOTf (8.4 $\mu \mathrm{L}, 77 \mu \mathrm{mol}$, 1.o eq) is added. The precipitated product is filtered off, washed with pentane $(3 \times 1.5 \mathrm{~mL})$ and extracted with benzene $(3 \times 0.5 \mathrm{~mL})$. Evaporation of the solvent i.vac. gives $\left[\mathrm{RuH}(\mathrm{OTf}) \mathrm{CO}\left(\mathrm{MePNP}^{\mathrm{PP}}\right)\right]$ as a white powder $(33 \mathrm{mg}$, $74 \%)$. Crystals suitable for X-ray crystallography were grown from a saturated solution of $\mathrm{Et}_{2} \mathrm{O}$ at $-40{ }^{\circ} \mathrm{C} .{ }^{1} \mathrm{H}\left\{{ }^{31} \mathrm{P}\right\}$ NMR $\left(500.25 \mathrm{MHz}, \mathrm{C}_{6} \mathrm{D}_{6}, 298 \mathrm{~K}\right): \delta(\mathrm{ppm})=2.69$ (hept, $\left.{ }^{3} J_{\mathrm{HH}}=7.2 \mathrm{~Hz}, 2 \mathrm{H}, \mathrm{CH}^{\text {syn }}\right), 2.06\left(\mathrm{~s}, 3 \mathrm{H}, \mathrm{NCH}_{3}\right), 1.91-1.82(\mathrm{~m}$, $4 \mathrm{H}, \mathrm{NCH}{ }^{i}$ superposition), 1.79 (hept, ${ }^{3} J_{\mathrm{HH}}=6.9 \mathrm{~Hz}, 2 \mathrm{H}$, $\left.\mathrm{CH}^{\text {anti }}\right), 1.60\left(\mathrm{~d},{ }^{3} J_{\mathrm{HH}}=7.2 \mathrm{~Hz}, 6 \mathrm{H}, \mathrm{CH}_{3}\right), 1.59^{-1.51}(\mathrm{~m}, 2 \mathrm{H}$, $\left.\mathrm{PCH}_{2}{ }^{\text {syn }}\right), 1.43^{-1.38}\left(\mathrm{~m}, 2 \mathrm{H}, \mathrm{PCH}_{2}\right), 1.06\left(\mathrm{~d},{ }^{3} J_{\mathrm{HH}}=6.9 \mathrm{~Hz}, 6 \mathrm{H}\right.$, $\left.\mathrm{CH}_{3}{ }^{\text {anti }}\right), \quad 0.97\left(\mathrm{~d},{ }^{3} J_{\mathrm{HH}}=7.2 \mathrm{~Hz}, 6 \mathrm{H}, \mathrm{CH}_{3}\right), \quad 0.73(\mathrm{~d}$, $\left.{ }^{3} J_{\mathrm{HH}}=6.9 \mathrm{~Hz}, 6 \mathrm{H}, \mathrm{CH}_{3}{ }^{\text {anti }}\right),-20.56\left(\mathrm{~s}, \mathrm{1H}, \mathrm{Ru}-H\left({ }^{2} J_{\mathrm{HP}}=19.0\right.\right.$ (1) (a) Park, S.; Chang, S. Catalytic Dearomatization of N-Heteroarenes with Silicon and Boron Compounds. Angew. Chem. Int. Ed. 2017, 56, 7720; (b) Lipke, M. C.; Liberman-Martin, A. L.; Tilley, T. D. Electrophilic Activation of Silicon-Hydrogen Bonds in Catalytic Hydrosilations. Angew. Chezm. Int. Ed. 2017, 56, 2260;
$\mathrm{Hz}$ by ${ }^{1} \mathrm{H}$ NMR)). ${ }^{13} \mathrm{C}\left\{{ }^{1} \mathrm{H}\right\}$ NMR (125.8o $\left.\mathrm{MHz}, \mathrm{C}_{6} \mathrm{D}_{6}, 298 \mathrm{~K}\right)$ : $\delta(\mathrm{ppm})=205.8 \quad\left(\mathrm{t}, \quad{ }^{2} J_{\mathrm{CP}}=12.1 \mathrm{~Hz}, \quad \mathrm{CO}\right), \quad 121.0 \quad(\mathrm{q}$, $\left.{ }^{1} J_{\mathrm{CF}}=320.1 \mathrm{~Hz}, \mathrm{CF}_{3}\right), 65.1\left(\mathrm{vt}, \mathrm{N}=\left|{ }^{2} J_{\mathrm{CP}}+{ }^{3} J_{\mathrm{CP}}\right|=9.0 \mathrm{~Hz}\right.$, $\left.\mathrm{NCH}_{2}\right), 45.6\left(\mathrm{~s}, \mathrm{NCH}_{3}\right), 29.9\left(\mathrm{vt}, \mathrm{N}=\left|{ }^{1} J_{\mathrm{CP}}+{ }^{3} J_{\mathrm{CP}}\right|=20.5 \mathrm{~Hz}\right.$, $\left.\mathrm{CH}^{\mathrm{syn}}\right)$, 28.1 (vt, $\left.\mathrm{N}=\left|{ }^{1} J_{\mathrm{CP}}+{ }^{3} J_{\mathrm{CP}}\right|=18.0 \mathrm{~Hz}, \mathrm{PCH}_{2}\right), 24.3$ (vt, $\mathrm{N}=\left|{ }^{1} J_{\mathrm{CP}}+{ }^{3} J_{\mathrm{CP}}\right|=26.6 \mathrm{~Hz}, \mathrm{C}$ ), 20.9 (superposition of two vt), $\left.\mathrm{N}=\left|{ }^{2} J_{\mathrm{CP}}+{ }^{4} J_{\mathrm{CP}}\right|=6.0 \mathrm{~Hz}, \mathrm{CH}_{3}\right), 19.2\left(\mathrm{~s}, \mathrm{CH}_{3}\right), 17.1(\mathrm{vt}, \mathrm{N}$ $\left.=\left|{ }^{2} J_{\mathrm{CP}}+{ }^{4} J_{\mathrm{CP}}\right|=3.5 \mathrm{~Hz}, \mathrm{CH}_{3}\right)$. Assignments were confirmed by $2 \mathrm{D}-\mathrm{NMR} .{ }^{31} \mathrm{P}\left\{{ }^{1} \mathrm{H}\right\}$ NMR $\left(202.52 \mathrm{MHz}, \mathrm{C}_{6} \mathrm{D}_{6}, 298 \mathrm{~K}\right)$ : $\delta(\mathrm{ppm})=68.8(\mathrm{~s}) .{ }^{19} \mathrm{~F}$ NMR $\left(470.67 \mathrm{MHz}, \mathrm{C}_{6} \mathrm{D}_{6}, 298 \mathrm{~K}\right)$ : $\delta(\mathrm{ppm})=-77.5(\mathrm{~s})$. LIFDI-MS: $\mathrm{m} / \mathrm{z}(\%)=599.1(4)[\mathrm{M}]^{+}$, 450.2 (100) [M-OTf] $]^{+}$IR: $v\left(\mathrm{~cm}^{-1}\right): 2960,2932,2873,2056$ (Ru-H), $1917(\mathrm{C} \equiv \mathrm{O}), 1460,1295,1235,1220,1155,1032,882$, 821, 695, 633, 518. Anal. calcd for $\mathrm{C}_{19} \mathrm{H}_{40} \mathrm{~F}_{3} \mathrm{NO}_{4} \mathrm{P}_{2} \mathrm{RuS}$ : C, 38.12; H, 6.74; N, 2.34. Found: C, 38.05; H, 6.72; N, 2.33 .

\section{ASSOCIATED CONTENT}

Detailed experimental procedures, characterization of products and computational details. This material is available free of charge via the Internet at http://pubs.acs.org.

\section{AUTHOR INFORMATION}

\section{Corresponding Authors}

*max.holthausen@chemie.uni-frankfurt.de; *sven.schneider@chemie.uni-goettingen.de

\section{Author Contributions}

AG performed all synthetic and spectroscopic work, supervised by SSch. JIS, USK and MD carried out the quantum chemical studies, supervised by $\mathrm{MCH}$. Crystallographic characterization was done by $\mathrm{CW}$. The manuscript was written by AG, JIS, MCH and SSch. All authors commented on the manuscript and approved the final version.

\section{ACKNOWLEDGMENT}

This paper is dedicated to Prof. Dr. Dietmar Stalke on the occasion of his $60^{\text {th }}$ birthday. The authors thank the European Research Council (ERC Grant Agreement 646747) and the Deutsche Forschungsgemeinschaft (CRC 1073, Project Co7) for funding and the graduate student program CaSuS (A.G.). Quantum-chemical calculations were performed at the Center for Scientific Computing (CSC) Frankfurt on the FUCHS and LOEWE-CSC high-performance compute clusters. Dr. C. Volkmann is acknowledged for recording parts of the crystallographic data.

\section{ABBREVIATIONS}

Rxn, reaction; OTf, triflate, trifluoromethanesulfonate $\left(\mathrm{O}_{3} \mathrm{SCF}_{3}{ }^{-}\right)$; eq, equivalents; $\mathrm{NMR}$, nuclear magnetic resonance; IR, infrared; LIFDI-MS, liquid injection field desorption ionization mass spectrometry; conv, conversion; $K_{\mathrm{eq}}$, equilibrium constant; c, concentration; $\Delta G^{\mathrm{o}}$, standard Gibbs free energy; $\mathrm{p} K_{\mathrm{a}, \mathrm{MeCN}}$, negative decadic logarithm of the acidity constant of the conjugate acid (measured in acetonitrile); $\mathrm{t}$, time; $\mathrm{h}$, hour(s); L, liter.

\section{REFERENCE}

(c) Obligacion, J. V.; Chirik, P. J. Electrophilic Activation of Silicon-Hydrogen Bonds in Catalytic Hydrosilations. Nat. Rev. Chem. 2018, 2, 15; (d) Chay, R. S.; Rocha, B. G. M.; Pombeiro, A. J. L.; Kukushkin, V. Y.; Luzyanin, K. V. Platinum 
Complexes with Chelating Acyclic Aminocarbene Ligands Work as Catalysts for Hydrosilylation of Alkynes. ACS Omega 2018, 3, 863.

(2) (a) Cheng, C.; Hartwig, J. F. Catalytic Silylation of Unactivated C-H Bonds Chem. Rev. 2015, 115, 8946; (b) Parasram, M.; Gevorgyan V. Silicon-Tethered Strategies for C-H Functionalization Reactions. Acc. Chem. Res. 2017, 50, 2038. (3) Toutov, A. A.; Salata, M.; Fedorov, A.; Yang, Y.-F.; Liang, Y.; Cariou, R.; Betz K. N.; Couzijn, E. P. A.; Shabaker, J. W.; Houk, K. N.; Grubbs, R. H. A potassium tert-butoxide and hydrosilane system for ultra-deep desulfurization of fuels. Nat. Energy 2017, 2, 17008.

(4) (a) Gauvin, F.; Harrod, J. F.; Woo, H.-G. in Adv. Organomet. Chem. West, R.; Hill, A., Eds.; Academic Press, 1998; Vol. 42, p. 363 (b) Waterman, R. Mechanisms of metal-catalyzed dehydrocoupling reactions. Chem. Soc. Rev. 2013, 42, 5629 .

(5) (a) Richards, R. D. C.; Hollingshurst, J.; Semlyen, J. A. Cyclic Polysiloxanes: 5. Preparation and Characterization of poly(hydrogenmethylsiloxane) Polymer, 1993, 34, 4965; (b) Li, J.; Ren, P.; Zhan, C.; Qin, J. Synthesis and structural characterization of novel multifunctional polysiloxanes having photo-refractive properties. Polym. Int. 1999, 48, 491; (c) Cancouët, P.; Daudet, E.; Hélary, G.; Moreau, M.; Sauvet, G. Functional polysiloxanes. I. Microstructure of poly(hydrogenmethylsiloxane-co-dimethylsiloxane)s obtained by cationic copolymerization. J. Polym. Sci. Part A Polym. Chem. 2ooo, 38, 826; (d) Beckmann, J.; Dakternieks, D.; Duthie, A.; Foitzik, R. C. The use of Pearlman's catalyst for the oxidation of $\mathrm{Si}-\mathrm{H}$ bonds. Synthesis, structures and acid-catalysed condensation of novel $\alpha, \omega$-oligosiloxanediols $\mathrm{HOSiMe}_{2} \mathrm{O}\left(\mathrm{SiPh}_{2} \mathrm{O}\right)_{n} \mathrm{SiMe}_{2} \mathrm{OH}(\mathrm{n}=1-4)$. Silicon Chem. 2004, 2, 27.

(6) Kalchauer, W.; Pachaly, B. in Handb. Heterog. Catal. Ertl, G.; Knözinger, H. Schüth, F.; Weitkamp, J., Eds.; Wiley-VCH, 2oo8, p. 2635.

(7) a) Kunai, A.; Ohshita, J. Selective synthesis of halosilanes from hydrosilanes and utilization for organic synthesis. J. Organomet. Chem. 20o3, 686, 3; b) Wang, W.; Tan, Y.; Xie, Z.; Zhang, Z. An efficient method to synthesize chlorosilanes from hydrosilanes. J. Organomet. Chem. 2014, 769, 29.

(8) Chulsky, K.; Dobrovetsky, R. B(C6F5)3-Catalyzed Selective Chlorination of Hydrosilanes. Angew. Chem. Int. Ed. 2017, 56, 4744.

(9) Previously, Hidai and coworkers proposed silyl triflate hydrogenolysis as one step in catalytic trimethylsilyl enol ether hydrogenolysis: Nishibayashi, Y. Takei, I.; Hidai, M. Angew. Chemie Int. Ed. 1999, 38, 3047. Takei, I.; Nishibayashi, Y.; Ishii, Y.; Mizobe, Y.; Uemura, S.; Hidai, M. J. Organomet. Chem. 2003, 679, 32.

(10) (a) Tsushima, D.; Igarashi, M.; Sato, K.; Shimada, S. Ir-Catalyzed Hydrogenolysis Reaction of Silyl Triflates and Halides with $\mathrm{H}_{2}$. Chem. Lett. 2017, 46, 1532. (b) Beppu, T.; Sakamoto, K.; Nakajima, Y.; Matsumoto, K.; Sato, K.; Shimada, S. Hydrosilane Synthesis via Catalytic Hydrogenolysis of Halosilanes Using a Metal-Ligand Bifunctional Iridium Catalyst. J. Organomet. Chem. 2018, 869, 75. (11) (a) Käß, M.; Friedrich, A.; Drees, M.; Schneider, Ruthenium Complexes with Cooperative PNP Ligands: Bifunctional Catalysts for the Dehydrogenation of Ammonia-Borane. Angew. Chem. Int. Ed. 2009, 48, 905; (b) Friedrich, A.; Drees, M.; Schneider, S. Ruthenium catalyzed Dimethylamineborane Dehydrogenation: Stepwise Metal Centered Dehydrocyclization. Chem. Eur. J. 2009, 15, 10339 (c) Staubitz, A.; Sloan, M. E.; Robertson, A. P. M.; Friedrich, A.; Schneider, S ; Gates, P. J.; Manners, I.; Schmedt auf der Günne, J. Catalytic Dehydrocoupling/Dehydrogenation of N-Methylamine-Borane and Ammonia-Borane: Synthesis and Characterization of High Molecular Weight Polyaminoboranes. $J$. Am. Chem. Soc. 2010, 132, 13332; (d) Marziale, A. N.; Friedrich, A.; Klopsch, I. Drees, M.; Celinski, V. R.; Schmedt auf der Günne, J.; Schneider, S. The Mechanism of Borane-Amine Dehydrocoupling with Bifunctional Ruthenium Catalysts. J. Am. Chem. Soc. 2013, 135, 13342; (e) Bielinski, E. A.; Lagaditis, P. O. Zhang, Y.; Mercado, B. Q.; Würtele, C.; Bernskoetter, W. H.; Hazari, N.; Schneider, S. Lewis Acid-Assisted Formic Acid Dehydrogenation Using a Pincer-Supported Iron Catalyst. J. Am. Chem. Soc. 2014, 136, 10234; (f) Chakraborty, S.; Lagaditis, P. O.; Förster, M.; Bielinski, E. A.; Hazari, N.; Holthausen, M. C.; Jones, W. D.; Schneider, S. Well-Defined Iron Catalysts for the Acceptorless Reversible Dehydrogenation-Hydrogenation of Alcohols and Ketones. ACS Catal. 2014, 4 3994; (g) Glüer, A.; Förster, M.; Celinski, V. R.; Schmedt auf der Günne, J.; Holthausen, M. C.; Schneider, S. Highly Active Iron Catalyst for Ammonia Borane Dehydrocoupling at Room Temperature. ACS Catal. 2015, 5, 7214; (h) Glüer, A. Schneider, S. Iron Catalyzed Hydrogenation and Electrochemical Reduction of $\mathrm{CO}_{2}$ : The Role of Functional Ligands. J. Organomet. Chem. 2018, 861, 159. (12) Lide, D. R. CRC Handbook of Chemistry and Physics; CRC Press, 2005. (13) The hydridicity $\left(\Delta G_{\mathrm{H}-}^{\mathrm{O}}\right)$ is defined as the free energy of heterolytic $\mathrm{M}-\mathrm{H}$ bond dissociation: $\mathrm{L}_{n} \mathrm{M}-\mathrm{H} \rightarrow \mathrm{Ln}_{n} \mathrm{M}^{+}+\mathrm{H}^{-}$. Better hydride donors are therefore defined by lower hydridicities.

For table of contents only:
(14) Wiedner, E. S.; Chambers, M. B.; Pitman, C. L.; Bullock, R. M.; Miller, A. J. M.; Appel, A. M. Thermodynamic Hydricity of Transition Metal Hydrides. Chem. Rev. 2016, 116, 8655 .

(15) (a) Liu, Q.; Wu, L.; Gülak, S.; Rockstroh, N.; Jackstell, R.; Beller, M. Towards a Sustainable production of formate salts: Combined catalytic methanol dehydrogenation and bicarbonate hydrogenation. Angew. Chem. Int. Ed. 2014, 53, 7085; (b) Kothandaraman, J.; Czaun, M.; Goeppert, A.; Haiges, R.; Jones, J. P.; May, R. B.; Prakash, G. K. S.; Olah, G. A. Amine-free reversible hydrogen storage in formate salts catalyzed by ruthenium pincer complex without $\mathrm{pH}$ control or solvent change. ChemSusChem 2015, 8, 1442; (c) Kothandaraman, J.; Goeppert, A.; Czaun, M.; Olah, G. A.; Prakash, G. K. S. $\mathrm{CO}_{2}$ capture by amines in aqueous media and its subsequent conversion to formate with reusable ruthenium and iron catalysts. Green Chem. 2016, 2, 156.

(16) Alberico, E.; Lennox, A. J. J.; Vogt, L. K.; Jiao, H.; Baumann, W.; Drexler, H.J.; Nielsen, M.; Spannenberg, A.; Checinski, M. P.; Junge, H.; Beller, M. Unravelling the Mechanism of Basic Aqueous Methanol Dehydrogenation Catalyzed by Ru-PNP Pincer Complexes. J. Am. Chem. Soc. 2016, 138, 14890.

(17) Besides hydrogenation, hydrolysis products mainly account for the residual conversion.

(18) Lambert, J. B.; Zhang, S.; Ciro, S. M. Silyl Cations in the Solid and in Solution. Organometallics 1994, 13, 2430.

(19) (a) Emde, H.; Simchen, G. Silylation of nitriles with trimethylsilyl trifluoromethanesulfonate (trimethylsilyl triflate). Synthesis 1977, 9, 636; (b) Todorova, Z.; Koseva, N.; Troev, K. Sylilation of poly(alkylene H-phosphonate)s - Rapid and efficient method for obtaining poly(alkylene trisilylmethylphosphite)s. Eur. Polym. J. 2015, 62, 87 .

(20) (a) Corey, E. J.; Cho, H.; Rücker, C.; Hua, D. H. Studies with trialkylsilyltriflates: new syntheses and applications. Tetrahedron Lett. 1981, 22, 3455; (b) Matyjaszewski, K.; Chen, Y. L. Synthesis and reactions of silanes containing two triflate groups. J. Organomet. Chem. 1988, 340, 7.

(21) See Supporting Information for full computational details.

(22) The effective activation barrier increases slightly for the full $H \mathrm{PNP}^{i \mathrm{Pr} 2}$-ligands $\left(\Delta^{\ddagger} \mathrm{G}=27.6 \mathrm{kcal} \mathrm{mol}^{-1}\right.$, see Supporting Information for details).

(23) The ${ }^{19} \mathrm{~F}$ NMR signals for $\mathrm{Me}_{2} \mathrm{SiClOTf}$ and $\mathrm{Me}_{2} \mathrm{SiOTf}_{2}$ collapse to a single resonance upon addition of base evidencing rapid triflate exchange. ${ }^{1} \mathrm{H}$ NMR and ${ }^{1} \mathrm{H}-{ }^{29} \mathrm{Si} \mathrm{HMBC}$ spectroscopy allow for unequivocal assignment of all equilibrium species.

(24) As only Si-OTf bonds are hydrogenated under these conditions, yields and conversions are given with respect to triflate vs 1,2,4,5-tetramethylbenzene as internal standard.

(25) (a) Stock, A.; Somieski, C. Siliciumwasserstoffe VI. I): Chlorierung und Methylierung des Monosilanes. Chem. Ber. 1919, 52, 695 (b) Whitmore, F. C.; Pietrusza, E. W.; Sommer, L. H. Hydrogen-Halogen Exchange Reactions of Triethylsilane. A New Rearrangement of Neopentyl Chloride. J. Am. Chem. Soc. 1947, 69, 2108. (c) Weyenberg, D. R.; Bey, A. E.; Ellison, P. J. The tetraalkylammoniumhalide-catalyzed redistribution of hydrogen and chlorine on silicon. J. Organomet. Chem. 1965, 3, 489. (d) Weyenberg, D. R.; Bey, A.; Stewart, H.; Atwell, $\mathrm{W}$. The redistribution of chlorine, fluorine, or methoxy with hydrogen on silicon. J. Organomet. Chem. 1966, 6, 583 .

(26) Kaljurand, I.; Kütt, A.; Sooväli, L.; Rodima, T.; Mäemets, V.; Leito, I.; Koppel, I. A. Extension of the Self-Consistent Spectrophotometric Basicity Scale in Acetonitrile to a Full Span of $28 \mathrm{pK}_{\mathrm{a}}$ Units: Unification of Different Basicity Scales. J. Org. Chem. 2005, 70, 1019.

(27) Lõkov, M.; Tshepelevitsh, S.; Heering, A.; Plieger, P. G.; Vianello, R.; Leito, I. On the Basicity of Conjugated Nitrogen Heterocycles in Different Media. European J. Org. Chem. 2017, 4475

(28) Under these conditions, $\mathrm{Me}_{2} \mathrm{SiClOTf}$ is the only detectable silyltriflate species by ${ }^{1} \mathrm{H}$ NMR spectroscopy.

(29) Yakelis, N. A.; Bergman, R. G. Safe Preparation and Purification of Sodium Tetrakis[(3,5-trifluoromethyl)phenyl]borate $\left(\mathrm{NaBAr}_{24}^{\mathrm{F}}\right)$ : Reliable and Sensitive Analysis of Water in Solutions of Fluorinated Tetraarylborates. Organometallics 2005, 24, 3579 .

(30) Curley, J. J.; Bergman, R. G.; Tilley, T. D. Preparation and physical properties of early-late heterobimetallic compounds featuring $\mathrm{Ir}-\mathrm{M}$ bonds $(\mathrm{M}=\mathrm{Ti}, \mathrm{Zr}, \mathrm{Hf})$. Dalton Trans. 2012, 41, 192.

(31) Bertoli, M.; Choualeb, A.; Lough, A. J.; Moore, B.; Spasyuk, D.; Gusev, D. G. Osmium and Ruthenium Catalysts for Dehydrogenation of Alcohols. Organometallics 2011, 30, 3479 .

(32) Han, Z.; Rong, L.; Wu, J.; Zhang, L.; Wang, Z.; Ding, K. Catalytic Hydrogenation of Cyclic Carbonates: A Practical Approach from $\mathrm{CO}_{2}$ and Epoxides to Methanol and Diols. Angew. Chem. Int. Ed. 2012, 51, 13041. 


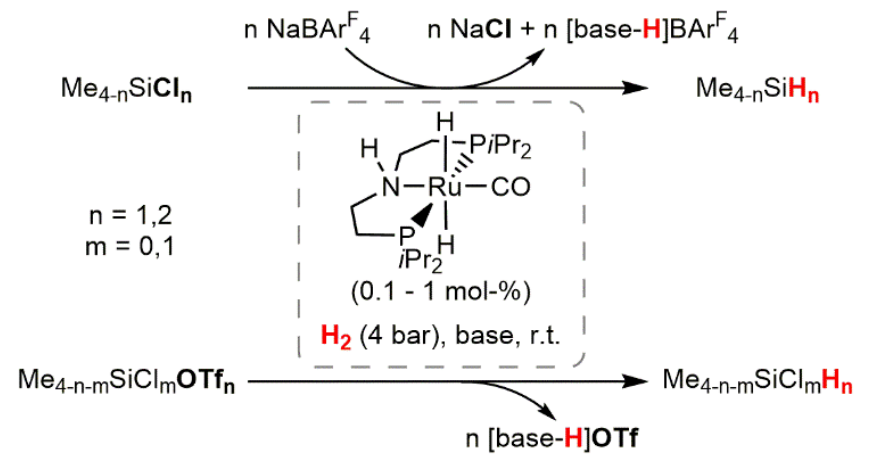

Synopsis: Catalytic hydrogenolysis of chlorosilanes and silyl triflates is reported at mild conditions using a bifunctional ruthenium catalyst. With $\mathrm{NEt}_{3}$ as base, chlorosilane hydrogenolysis requires additional driving force, e.g. by chloride abstraction with $\mathrm{NaBAr}_{4}^{\mathrm{F}}$. In contrast, silyl triflate hydrogenolysis is facile without additive, giving $\mathrm{Me}_{3} \mathrm{SiH}, \mathrm{Me}_{2} \mathrm{SiH}_{2}$ and $\mathrm{Me}_{2} \mathrm{Si}-$ $\mathrm{HOTf}$ in high yields and selectivity. Hydrogenolysis of chlorosilane/silyl triflate mixtures gives access to valuable $\mathrm{Me}_{2} \mathrm{SiClH}$ in yields over $50 \%$. 